\title{
FACET ORIENTATION AND TROPISM: ASSOCIATION WITH ACCELERATED DEGENERATION OF STABILIZING STRUCTURES IN LOWER LUMBAR SPINE
}

\author{
Vjekoslav Jeleč $\check{c}^{1}$, Rajka Turner², Miljenko Franić3 ${ }^{3}$, Anđelko Korušić ${ }^{4}$ and Krešimir Rotim ${ }^{5}$
}

${ }^{1}$ Department of Neurosurgery, Dubrava University Hospital, Zagreb, School of Medicine, Josip Juraj Strossmayer University, Osijek; ${ }^{2}$ Private Practice, Zagreb; ${ }^{3}$ Department of Orthopedics, ${ }^{4} \mathrm{Clinical}$ Department of Anesthesiology, Resuscitation and Intensive Care, Dubrava University Hospital, Zagreb, School of Medicine, Josip Juraj Strossmayer University, Osijek; ${ }^{5}$ Clinical Department of Neurosurgery, Sestre milosrdnice University Hospital Center, Zagreb, Croatia

\begin{abstract}
SUMMARY - The influence of facet orientation and tropism on the process of spinal degeneration has been extensively studied during the last few decades, but there are still many controversies and conflicting results in this field of research. The biomechanical cause of accelerated degeneration of stabilizing structures in lower lumbar spine lies within the combination of several factors, but two most important ones are compressive load and more coronal facet orientation that offers less resistance against torsional loading. Axial rotation of lower lumbar spine is undoubtedly associated with higher strain in disc annulus, and enhanced range of secondary rotational movements may be even more significant for the progression of annular degeneration. Accordingly, more pronounced facet tropism could be having part in faster progression of disc degeneration in lower lumbar spine, as indicated by a number of recent studies. More sagittal facet orientation in patients with a higher facet osteoarthritis score at lower lumbar segments is very likely related to arthritic remodeling commonly seen in other synovial joints. There is also a possibility that it could be associated with the adaptation to partial loss of lumbar lordosis, as both coincide with advanced age.
\end{abstract}

Key words: Intervertebrae disc, degeneration; Lumbar vertebrae - radigraphy; Magnetic resonance imaging; Osteoarthritis; Biomechanical phenomena; Pressure; Tropism

\section{Introduction}

Facet or zygapophyseal joints are true diarthrodial articulations situated on dorsolateral aspect of the spine ${ }^{1}$. Apart from resisting vertebral translation, those paired bony pillars add to spinal stability by supporting between $3 \%$ and $33 \%$ of compressive load, depending on current body position, and by facilitating or restricting movement in various spinal regions ${ }^{2-6}$. Their complex anatomy and biomechanical performance have a tremendous influence on overall

Correspondence to: Rajka Turner, DVM, Slavonska 10, HR10000 Zagreb, Croatia

E-mail: turner.rajka@gmail.com

Received February 11, 2016, accepted March 11, 2016 spinal kinematic function. Unlike intervertebral disc that allows motion in all directions and acts primarily through dissipating compressive load and resisting rotation, movements of facet joints are restricted by the form of their articulation, orientation, and capsular attachments ${ }^{3}$. Articular surfaces covered with hyaline cartilage provide low friction interface that facilitates motion during normal conditions in a healthy spine, while fibrous capsule resists tensile forces developing across the joint and mainly serves to limit rotation and prevent backward sliding motion during spinal extension $^{7,8}$. Facet joints are more coronally oriented with respect to midsagittal plane in cervical and upper thoracic spine, permitting the significant range of coupled motions of axial rotation with lateral bend- 
ing, whereas their mostly sagittal orientation in lumbar spine limits rotational movement to about $2^{\circ}$, but instead allows the significant range of motion in sagittal plane, i.e. ventral flexion and extension ${ }^{4,9,10}$. However, between L3 and S1 spinal level, facet orientation slightly changes to coronal thus facilitating more rotational movement, but also producing less mobility in the sagittal plane $e^{1,11-14}$. Facet asymmetry or tropism is defined as a difference between the left and right facet angle, and although believed to be a normal feature of thoracic spine, in lumbar region more pronounced facet asymmetry is considered to be a possible cause of abnormal loading patterns that eventually may lead to pathologic conditions s $^{1,12,15-17}$.

In previous studies involving lower lumbar segments, more coronal facet orientation and tropism were found to be associated with a higher risk of developing spondylolysis ${ }^{18-20}$, whereas more sagittal facet orientation positively correlated with advanced age of tested subjects and increased possibility of developing degenerative spondylolisthesis ${ }^{6,16,21}$. On the other hand, many studies dealing with the role of facet orientation and tropism in the process of degeneration of spinal stabilizing structures showed rather conflicting results $5,6,16,17,22-29$. By reviewing the relevant literature in the field, we made an attempt to elucidate whether, and to what extent the facet orientation and asymmetry contributes to faster progression of degenerative disease in lower lumbar spine.

\section{Spinal Degeneration, Instability and Pain}

The process of degeneration of spinal stabilizing structures starts as early as during the second decade of life and, particularly in the intervertebral discs, it tends to become more severe with increasing age, as well as from cranial to caudal levels ${ }^{30,31}$. Disc degeneration and facet joint osteoarthritis, until they reach the final stage with collapsed intervertebral space and severe subchondral sclerosis in facet joints, commonly lead to segmental instability, i.e. excessive motion under physiological loading of the spine $^{11,31-35}$. It has been estimated that there is a $50 \%$ to $70 \%$ chance for a person to experience low back pain at some time during lifetime, and although the specific causes are still largely unknown, spinal instability has recently been recognized as one of the most probable causes of low back pain ${ }^{9}$. The pain may arise from direct compression of neural structures, or during abnormal deformation of annular fibers, ligaments, endplates and joint capsules that are known to contain a significant number of nociceptors ${ }^{2}$. In this way, dynamic, so-called occult lateral spinal stenosis in neural foramina can develop under physiological loading in motion segments that are severely affected by disc degeneration, especially during spinal extension when nerve root usually becomes entrapped by hypertrophied ligamentum flavum, intervertebral disc, or both ${ }^{36}$. Disc degeneration normally precedes facet osteoarthritis, in some cases by 20 years or more, and in general, facet joint osteoarthritis is unlikely to be seen in the absence of disc degeneration ${ }^{2,10,30,32,35}$. In most cases, osteoarthritic changes are minimal under 40 years of age, whereas after 50 subchondral sclerosis and forming of osteophytes are more frequently observed $^{30}$. A recently conducted $3 \mathrm{D}$ CT in vivo study showed that subjects with chronic low back pain have a greater age-related increase of facet joint articular surface when compared with asymptomatic individuals. The authors hypothesized that the most probable reason for that is adaptation to the increased load created by the loss of disc height and forming of osteophytes that with time become completely integrated into the joint surface ${ }^{37}$. Together with ligament hypertrophy and calcification, forming of spondylophytes is considered to be the final stage of degenerative disc disease, and this process is, in fact, part of a defensive strategy that serves to limit pathologically increased range of intervertebral motion ${ }^{31}$. Unfortunately, such restabilization is very often associated with radicular pain that results from lateral recess stenosis and spinal nerve compression that sometimes requires surgical treatment. Inflammatory changes that closely correlate with disc degeneration and are occasionally seen in vertebral endplates, i.e. Modic magnetic resonance imaging (MRI) changes, are also believed to be the possible source of low back pain ${ }^{38}$.

\section{Loading Conditions and Rotational Strain in Lower Lumbar Spine}

It has been hypothesized that axial rotation of lumbar spine may contribute to accelerated disc degeneration by causing increased shearing load on disc annulus due to the location of the center of rotation in that region which is, especially at the lumbosacral 
junction, located posteriorly to the disc ${ }^{39}$. During axial rotation of lower lumbar spine, the instantaneous center of rotation with increasing torque migrates toward compressed facet, i.e. facet joint on the side of rotation ${ }^{39,40}$. In that moment, the compressed facet is a pivot around which all other structures rotate, while anterior annulus represents the stabilizing structure that is placed farthest from that center of rotation and, therefore, has the longest moment arm, which makes it most effective in resisting rotation. Considering that torque or moment of force is a product of force magnitude and its distance from the axis of rotation, i.e. moment arm, applying force through the longer moment arm results in higher loading of the structure in question ${ }^{41}$. In view of these facts, it seems very likely that the annulus, and especially its anterior part, may be submitted to great amount of strain during axial rotation of lower lumbar spine, while discs in upper lumbar segments are apparently better protected from excessive torsional loading as a result of having more sagittally oriented facet joints that limit rotational movements ${ }^{13}$. This may account for thicker and stronger fibers normally found in the anterior annulus, along with localized increase in collagen fiber concentration frequently observed on $\mathrm{T} 2$ weighted MRI images of lumbar discs in healthy subjects as young as 20 or 30 years of age ${ }^{42}$. Schmidt et al..$^{43}$ in their finite element study of the L4-L5 segment also predicted the highest strain in annular fibers during axial rotation, but their simulation demonstrated that the strain was highest in the posterolateral region of the annulus, offering an explanation for the most common location of disc hernia. They also concluded that annulus is most likely to fail in combined loading of axial rotation with lateral or ventral bending and that shear and fiber strain tend to increase with increasing axial load. Accordingly, it seems that besides larger range of axial rotation, the cause of accelerated disc degeneration in lower lumbar spine may also be found in increased axial loading induced by supporting upper body weight, which is then significantly augmented by lifting or carrying any additional load, or even during dynamic daily activities such as jogging, etc. ${ }^{4,44}$. Indeed, low hydrostatic pressure was found to have little influence on gene expression in human nucleus pulposus cells, showing a tendency to even increase anabolic protein expression (aggrecan and collagen type 1), while high hydrostatic pressure caused an increase in expression of catabolic enzymes (matrix metalloproteinases) and suppressed anabolic response at the same time, thus accelerating matrix turnover and degeneration process ${ }^{2,45,46}$. This may also be the reason why both taller stature and increased body mass index were found to have clear association with higher incidence of lumbar disc hernia that requires surgical treatment ${ }^{47,48}$.

\section{Facet Orientation, Tropism and Spinal Degeneration}

Many studies dealing with the role of facet tropism in spinal mechanical disorders showed highly controversial results ${ }^{5,6,16,17,22-25,28}$. By most authors, facet tropism is considered to be an inherited feature and apparently unassociated with age, gender or ethnic group, but in some cases could be related to asymmetric loading patterns or existing deformities such as scoliosis ${ }^{12,16,17}$. There have also been suggestions that facet tropism could be acquired as a result of so-called facet joint asymmetric sagittalization ${ }^{15}$. Farfan and Sullivan ${ }^{49}$ postulated that facet asymmetry could be an important factor in the etiology of disc hernia, explaining that more frontally oriented facet joint provides less mechanical resistance against axial torque, leading to excess rotational strain and eventually damage to the annulus fibrosus. On the other hand, others have suggested that axial rotation sufficient to cause disc injury may only be possible after facet joints have failed, and that it should be coupled with other motions such as flexion to result in this outcome ${ }^{50,51}$. Kong et al. ${ }^{17}$ failed to demonstrate any significant correlation between facet tropism and disc degeneration score, as well as Boden et al. ${ }^{23}$, who only recorded positive correlation between disc herniation and increased severity of facet tropism in symptomatic patients. Karacan et al. ${ }^{15}$ associated facet tropism with disc herniation, but they also observed increased asymmetry and more sagittal facet orientation in patients who were taller.

On the contrary, by separately analyzing adult and adolescent population, Lee et al..$^{25}$ did not find any significant association between facet tropism and incidence of disc hernia. Kunakornsawat et al. ${ }^{26}$ recorded the same results, although the average difference in facet joint angle was higher in patients with disc 
hernia. Ishihara et al. ${ }^{52}$ compared facet joint asymmetry between adolescent and adult patients with lumbar disc herniation and discovered that adolescents had a five times higher incidence of facet asymmetry. The authors also hypothesized that patients with facet joint asymmetry could be at a higher risk of developing disk herniation at an earlier age than those with more symmetrical facet joints.

Interestingly, Pietila et al. ${ }^{53}$, who studied lumbar disc herniation in patients aged up to 25 , emphasize that unlike more mature population, the primary cause of disc herniation in the young could be spinal overstraining resulting from postural anomaly such as scoliosis rather than disc degeneration. Along with elevated body mass index, the condition of bony structures and ligaments is considered to be the major predisposing factor in the etiology of disc hernia in young patients. However, they also believe that disc herniation in healthy individuals with intact intervertebral disc may only be caused by a very violent trauma such as falling off a trampoline.

By analyzing three most caudal lumbar segments (L3-L4 to L5-S1) in 46 subjects younger than 50, Noren et al..$^{54}$ found significant correlation between facet tropism and disc degeneration score on all three segments, but failed to observe any significant association between facet orientation and disc degeneration score. Pichaisak et al. ${ }^{6}$ also demonstrated significant association between disc degeneration score and facet tropism, but only at L4-L5 segment. Dai and Jia ${ }^{22}$ in results of their study also support the etiologic significance of facet asymmetry in degenerative disease of lumbar spine, but also emphasize that many controversies concerning this subject should be resolved by further investigation. By using kinetic MRI in order to investigate association between the degree of facet tropism and the amount of static and dynamic disc bulge in lumbar spine, Do et al. ${ }^{28}$ found significant correlation between severe tropism $\left(\geq 11^{\circ}\right)$ and increased maximal static and dynamic disc bulge at L4-L5 segment, but also associated severe tropism with increasing age. Disc bulge has been linked with annular radial tears and is considered to increase with progression of the disc degeneration process. Park et al..$^{55}$ made comparison between far lateral and posterolateral lumbar disc herniation with regard to facet tropism and suggested that differences in the degree of facet tropism might be the key factor in the development of far lateral as opposed to posterolateral disc herniation. On the other hand, Lee and $\mathrm{Lee}^{27}$ failed to observe any significant difference between far lateral and posterolateral lumbar disc herniation with respect to facet tropism.

Intervertebral disc and facet joints together form the functional spinal unit, and even though considered to be multifactorial, the etiology of facet joint osteoarthritis is closely related to disc degeneration and aging process ${ }^{3,21,30}$. Disc space narrowing has been proven to have an impact on facet function by causing marked increase in peak pressure across the joint ${ }^{56}$. There is also segmental instability, which in the form of pathologically increased range of motion caused by disc degeneration process applies more stress to facet joints, finally resulting in osteoarthritis and facet joint degeneration ${ }^{21,31-32,37}$.

During spinal flexion, facet joints remain unloaded, while in all other directions applying higher loads strongly increases the resulting forces in facet joints ${ }^{40}$. Facet joints are especially loaded during axial rotation, hence these high facet forces cause the instantaneous center of rotation to migrate posteriorly, outside the disc. Of all movements of lower lumbar spine, axial rotation is associated with the highest risk of injuries of the spinal segment ${ }^{57}$. Considering all this, one might expect that facet orientation could be an important factor in progression of facet joint osteoarthritis, especially in lower lumbar spine which is influenced by tremendous forces. Grogan et al. ${ }^{24}$ analyzed the complete lumbar spine from T12-L1 to L5S1 motion segment and observed a higher facet osteoarthritis score in subjects with more coronal facet orientation. Jentzsch et al. ${ }^{5}$ also associated more severe facet osteoarthritis with more coronal facet orientation, but only in upper lumbar spine (L2-L3), while finding no such correlation in lower lumbar segments. Kalichman et al. ${ }^{16}$ noted a slightly higher occurrence of facet osteoarthritis in patients with more sagittally oriented facet joints at L4-L5 and L5-S1 segments, but significant association was found only at L4-L5 level. In addition, there was no significant correlation between tropism and facet osteoarthritis score at any spinal level either. On the other hand, Kong et al. ${ }^{17}$ demonstrated significant correlation between facet asymmetry and high facet osteoarthritis score at L4- 
L5 motion segment, but few other authors found no sufficient evidence to confirm these results ${ }^{5,24}$.

Facet joints have been thought to acquire their final orientation and shape depending on loading conditions during childhood ${ }^{1}$. However, research data from a number of recent studies suggest that it seems more likely that they continue remodeling throughout life. By trying to find an association between lumbar facet orientation and age, Wang and Yang ${ }^{21}$ found negative correlation between more coronal facet orientation and advanced age at L4-L5 segment, which brought the conclusion that aging process contributes to the higher incidence of degenerative spondylolisthesis in older individuals due to more sagittal facet orientation in lower lumbar segments. Lau et al. ${ }^{29}$ demonstrated a significantly more sagittal mean facet angle in segments with degenerative spondylolisthesis, and so did Pichaisak et al. ${ }^{6}$, who also suggest that more sagittal facet orientation represents secondary remodeling rather than preexisting morphology. Furthermore, Lau et al. ${ }^{29}$ noted strong correlation between more sagittal facet orientation and facet joint osteoarthritis, advanced disc degeneration and disc herniation at all three segments of lower lumbar spine, which could be interpreted in a similar way. Kalichman et al. ${ }^{16}$ also demonstrated correlation between age and facet orientation, particularly at L4-L5 segment, and suggest that either more sagittal facet orientation predisposes to facet osteoarthritis or, which seems even more likely, more sagittal facet orientation in older subjects could be a result of arthritic remodeling process ${ }^{7,16}$.

\section{Conclusion}

Many studies have been dealing with the role of facet orientation and tropism in the progression of degeneration of spinal stabilizing structures, but there are still many controversies and conflicting results in this field of research. The most probable reason for this is different methodology used to obtain the results, and especially, different criteria that the authors used to define facet tropism.

The biomechanical cause of accelerated degeneration of stabilizing structures in lower lumbar spine lies within the combination of several factors, but two most important ones are compressive load and more coronal facet orientation that offers less resistance against torsional loading. Apart from facilitating rotational movements of pelvic girdle commonly occurring during normal bipedal walk, more coronally oriented facet joints also restrict dorsoventral vertebral translation, so this particular morphological feature may be a result of adaptation to increased shearing forces influencing human lower lumbar spine due to maintaining upright posture and the existence of physiological lumbar lordosis. Axial rotation of lower lumbar spine is undoubtedly associated with higher strain in disc annulus, and enhanced range of secondary rotational movements, i.e. movements made along the axes secondary to those of applied load due to curved shape of facet joints, may be even more significant for the progression of annular degeneration. Accordingly, it seems very possible that more pronounced facet tropism has a part in faster progression of disc degeneration in lower lumbar spine, as indicated by a number of recent studies. Facet tropism probably has no greater influence on progression of facet joint osteoarthritis; however, facet joint remodeling is a lifelong process that depends on various loading conditions, and more sagittal facet orientation in patients with a higher facet osteoarthritis score at lower lumbar segments is most likely related to arthritic remodeling commonly seen in other synovial joints. Moreover, it seems possible that more sagittal facet orientation could be biomechanically associated with partial loss of lumbar lordosis as a form of adaptation to altered loading conditions, hence it apparently coincides with advanced age.

\section{References}

1. Mahato NK. Facet dimensions, orientation and symmetry at L5-S1 junction in lumbosacral transitional states. Spine. 2011;36:569-73, 10.1097/BRS.0b013e3181f6ecb2.

2. An HS, Masuda K, Inoue N. Intervertebral disc degeneration: biological and biomechanical factors. J Orthop Sci. 2006;11:541-52, 10.1007/s00776-006-1055-4

3. Varlotta GP, Lefkowitz TR, Schweitzer M, Errico TJ, Spivak J, Bendo JA, et al. Lumbar facet joint: a review of the current knowledge: Part 1: Anatomy, biomechanics, and grading. Skeletal Radiol. 2010;40(1):13-23, 10.1007/s00256010-0983-4.

4. Miele VJ, Bhala T, Jones GA, Benzel EC. Concepts and mechanisms of spinal biomechanics. In: Winn R, editor. Youmans Neurological Surgery: Expert Consult. Philadelphia: Saunders-Elsevier; 2011. p. 2700-10. 
5. Jentzsch T, Geiger J, Zimmermann SM, Slankamenac K, Nguyen-Kim TDL, Werner CML. Lumbar facet joint osteoarthritis is associated with more coronal orientation of the facet joints at the upper lumbar spine. Radiol Res Pract. 2013;693971, 10.1155/2013/693971

6. Pichaisak W, Chotiyarnwong C, Chotiyarnwong P. Facet joint orientation and tropism in lumbar degenerative disc disease and spondylolisthesis. J Med Assoc Thai. 2015;98(4):373-9.

7. Kalichman L, Hunter DJ. Lumbar facet joint osteoarthritis. A review. Semin Arthritis Rheum. 2007;37(2):69-80, 10.1016/j.semarthrit.2007.01.007

8. Jaumard NV, Welch WC, Winkelstein BA. Spinal facet joint biomechanics and mechanotransduction in normal, injury and degenerative conditions. J Biomech Eng. 2011;133(7):071010, 10.1115/1.4004493

9. Panjabi MM. Clinical spinal instability and low back pain. J Electromyogr Kinesiol. 2003;13(4):371-9, 10.1016/S10506411(03)00044-0

10. Cubuk R, Kozakcioglu M, Tasali N, Atalay A, Celik L. Lumbar disc and facet degeneration: correlation with age and facet orientation. Trakya Univ Tip Fak Derg. 2009;26(1):36-42.

11. Haughton VM, Rogers B, Meyerand EM, Resnick DK. Measuring the axial rotation of lumbar vertebrae in vivo with MR imaging. Am J Neuroradiol. 2002;23:1110-6.

12. Masharawi Y, Rothschild B, Dar G, Peleg S, Robinson D, Been $\mathrm{E}$, et al. Facet orientation in the thoracolumbar spine: three-dimensional anatomic and biomechanical analysis. Spine 2004;29(16):1755-63,10.1097/01.BRS.0000134575.04084.EF

13. Kozanek M, Wang S, Passias PG, Xia Q, Li G, Bono $\mathrm{CM}$, et al. Range of motion and orientation of the lumbar facet joints in vivo. Spine. 2009;34(19):E689-96, 10.1097/ BRS.0b013e3181ab4456.

14. Toyone T, Ozawa T, Kamikawa K, Watanabe A, Matsuki K, Yamashita $\mathrm{T}$, et al. Facet joint orientation difference between cephalad and caudad portions: a possible cause of degenerative spondylolisthesis. Spine. 2009;34(21):2259-62, 10.1097/ BRS.0b013e3181b20158.

15. Karacan I, Aydin T, Sahin Z, Cidem M, Koyuncu H, Aktas I, et al. Facet angles in lumbar disc herniation: their relation to anthropometric features. Spine. 2004;29(10):1132-6, 10.1097/00007632-200405150-00016

16. Kalichman L, Suri P, Guermazi A, Li L, Hunter DJ. Facet orientation and tropism: association with facet joint osteoarthritis and degeneratives. Spine. 2009;34(16):E579-85, 10.1097/BRS.0b013e3181aa2acb.

17. Kong MH, He W, Tsai YD, Chen NF, Keorochana G, Do DH, et al. Relationship of facet tropism with degeneration and stability of functional spinal unit. Yonsei Med J. 2009;50(5):624-9, 10.3349/ymj.2009.50.5.624

18. Masharawi YM, Alperovitch-Najenson D, Steinberg N, Dar G, Peleg S, Rothschild B, et al. Lumbar facet orientation in spondylolysis: a skeletal study. Spine. 2007;32(6):E176-80, 10.1097/01.brs.0000257565.41856.0f
19. Don AS, Robertson PA. Facet joint orientation in spondylolysis and isthmic spondylolisthesis. J Spinal Disord Tech. 2008;21:112-5, 10.1097/BSD.0b013e3180600902

20. Rankine JJ, Dickson RA. Unilateral spondylolysis and the presence of facet joint tropism. Spine. 2010;35(21):E1111-4.

21. Wang J, Yang X. Age related changes in the orientation of lumbar facet joints. Spine. 2009;34(17):E596-8, 10.1097/ BRS.0b013e3181abbf1e

22. Dai L, Jia L. Role of facet asymmetry in lumbar spine disorders. Acta Orthop Belg. 1996;62(2):90-3.

23. Boden SD, Riew KD, Yamaguchi K, Branch TP, Schellinger $\mathrm{D}$, Wiesel SW. Orientation of the lumbar facet joints: association with degenerative disc disease. J Bone Joint Surg Am. 1996;78(3):403-11.

24. Grogan J, Nowicki BH, Schmidt TA, Haughton VM. Lumbar facet joint tropism does not accelerate degeneration of the facet joints. Am J Neuroradiol. 1997;18(7):1325-9.

25. Lee DY, Ahn Y, Lee SH. The influence of facet tropism on herniation of the lumbar discs in adolescents and adults. J Bone Joint Surg Br. 2005;88(4):520-3, 10.1302/0301-620X.88B4.16996

26. Kunakornsawat S, Ngamlamaidt K, Tungsiripat R, Prasartritha $\mathrm{T}$. The relationship of facet tropism to lumbar disc herniation. J Med Assoc Thai. 2007;90(7):1337-41.

27. Lee DY, Lee S-H. Effects of facet tropism and disc degeneration on far lateral lumbar disc degeneration: comparison with posterolateral lumbar disc herniation. Neurol Med Chir. 2009;49:57-61, http://doi.org/10.2176/nmc.49.57

28. Do DH, Taghavi CE, Fong W, Kong MH, Morishita Y, Wang JC. The relationship between degree of facet tropism and amount of dynamic disc bulge in lumbar spine of patients symptomatic for low back pain. Eur Spine. 2011;20(1):71-8, 10.1007/s00586-010-1558-8

29. Lau YYO, Chan CLY, Kwok KO, Griffith JF, Law SW, Fung KY. Orientation and osteoarthritis of lumbar facet joints: association with degenerative disk disease. Global Spine J. 2012;02-ST02, 10.1055/s-0032-1319865

30. Fujiwara A, Tamai K, Yamato M, An HS, Yoshida H, Saotome $\mathrm{K}$, et al. The relationship between facet joint osteoarthritis and disc degeneration of the lumbar spine: an MRI study. Eur Spine. 1999;8(5):396-401, 10.1007/s005860050193

31. Quint U, Wilke H-J. Grading of degenerative disk disease and functional impairment: imaging vs patho-anatomical findings. Eur Spine J. 2008;17:1705-13, 10.1007/s00586-008 $-0787-6$

32. Fujiwara A, Lim TH, An HS, Tanaka N, Jeon CH, Andersson GB, et al. The effect of disc degeneration and facet joint osteoarthritis on the segmental flexibility of the lumbar spine. Spine. 2000;25(23):3036-44.

33. Haughton VM, Schmidt TA, Keele K, An HS, Lim TH. Flexibility of lumbar spinal motion segments correlated to type of tears in the annulus fibrosus. J Neurosurg. 2000;92(1):81-6, 10.3171/spi.2000.92.1.0081 
34. Rohlmann A, Zander T, Schmidt H, Wilke H-J, Bergmann $\mathrm{G}$. Analysis of the influence of disc degeneration on the mechanical behavior of a lumbar motion segment using the finite element method. J Biomech. 2006;39:2484-90, 10.1016/j. jbiomech.2005.07.026

35. Kong MH, Morishita Y, He W, Miyazaki M, Zhang H, Wu $\mathrm{G}$, et al. Lumbar segmental mobility according to the grade of the disc, the facet joint, the muscle, and the ligament pathology by using kinetic magnetic resonance imaging. Spine. 2009;34(23):2537-44, 10.1097/BRS.0b013e3181b353ea

36. Nowicki BH, Haughton VM, Schmidt TA, Lim T-H, An HS, Riley LH, et al. Occult lumbar lateral spinal stenosis in neural foramina subjected to physiological loading. Am J Neuroradiol. 1996;17:1605-14.

37. Otsuka Y, An HS, Ochia RS, Andersson GB, Espinosa Orias AA, Inoue N. In vivo measurement of lumbar facet joint area in asymptomatic and chronic low back pain subjects. Spine. 2010;35(8):924-8, 10.1097/BRS.0b013e3181c9fc04

38. Yu LP, Qian WW, Yin GY, Ren YX, Hu ZY. MRI assessment of lumbar intervertebral disc degeneration with lumbar degenerative disease using the Pfirrmann grading system. PLoS One. 2012;7(12):e48074, http://dx.doi.org/10.1371/ journal.pone.0048074

39. Haher TR, O’Brien M, Felmly WT, Welin D, Perrier G, Choueka J, et al. Instantaneous axis of rotation as a function of the three columns of the spine. Spine. 1992;17(6):S14954.

40. Schmidt H, Heuer F, Claes L, Wilke HJ. The relation between the instantaneous center of rotation and facet joint forces - a finite element analysis. Clin Biomech. 2008;23:270-8, 10.1016/j.clinbiomech.2007.10.001

41. Benzel EC, Kayanja M, Fleischman A, Roy S. Spine biomechanics: fundamentals and future. Clin Neurosurg. 2006;53:98-105, 0148-703/06/5301-0098

42. Grenier N, Baulny D, Senegas J, Caille JM. Lumbar intervertebral disc and facet joints: normal and pathological. In: Manelfe C, editor. Imaging of the Spine and Spinal Cord. New York: Raven Press; 1992. p. 257-67.

43. Schmidt H, Kettler A, Heuer F, Simon U, Claes L, Wilke HJ. Intradiscal pressure, shear strain and fiber strain in the intervertebral disc under combined loading. Spine. 2007;32(7):748-55, 10.1097/01.brs.0000259059.90430.c2

44. Schmidt H, Shirazi-Adl A, Galbusera F, Wilke HJ. Response analysis of the lumbar spine during regular daily activities a finite element analysis. J Biomech. 2010;43(10):1849-56, 10.1016/j.jbiomech.2010.03.035
45. Lotz JC. Animal models of intervertebral disc degeneration: lessons learned. Spine. 2004;29(23):2742-50.

46. Neidlinger-Wilke C, Würtz K, Urban JP, Börm W, Arand $\mathrm{M}$, Ignatius A, et al. Regulation of gene expression in intervertebral disc cells by low and high hydrostatic pressure. Eur Spine. 2006;15(3):S372-8, 10.1007/s00586-006-0112-1

47. Heliovaara M. Body height, obesity, and risk of herniated lumbar intervertebral disc. Spine. 1987;12(5):469-72, 10.1097/00007632-198706000-00009

48. Bostman OM. Body mass index and height in patients requiring surgery for lumbar intervertebral disc herniation. Spine. 1993;18(7):851-4.

49. Farfan HF, Sullivan JD. The relation of facet orientation to intervertebral disc failure. Can J Surg. 1967;10(2):179-85.

50. Shirazi-Adl A, Ahmed AM, Shrivastava SC. Mechanical response of a lumbar motion segment in axial torque alone and combined with compression. Spine. 1986;11(9):914-27, 10.1097/00007632-198611000-00012

51. Ahmed AM, Duncan NA, Burke DL. The effect of facet geometry on the axial torque-rotation response of lumbar motion segments. Spine. 1990;15(5):391-401, 10.1097/00007632199005000-00010

52. Ishihara H, Matsui H, Osada R, Ohshima H, Tsuji H. Facet joint asymmetry as a radiologic feature of lumbar intervertebral herniation in children and adolescents. Spine. 1997;22(17):2001-4, 10.1097/00007632-199709010-00012

53. Pietila TA, Stendel R, Kombos T, Ramsbacher J, Schulte T, Brock M. Lumbar disc herniation in patients up to 25 years of age. Neurol Med Chir. 2001;41:340-4, http://doi. org/10.2176/nmc. 41.340

54. Noren R, Trafimow J, Andersson GB, Huckman MS. The role of facet joint tropism and facet angle in disc degeneration. Spine. 1991;16(5):530-2, 10.1097/00007632-19910500000008

55. Park JB, Chang H, Kim KW, Park SJ. Facet tropism: a comparison between far lateral and posterolateral lumbar disc herniation. Spine. 2001;26(6):667-9.

56. Dunlop RB, Adams MA, Hutton WC. Disc space narrowing and the lumbar facet joints. J Bone Joint Surg Br. 1984;66(5):706-10.

57. Schmidt H, Heuer F, Wilke HJ. Interaction between finite helical axes and facet joint forces under combined loading. Spine. 2008;33(25):2741-8, 10.1097/BRS.0b013e31817c4319 
Sažetak

\section{ORIJENTACIJA I ASIMETRIJA FASETNIH ZGLOBOVA: POVEZANOST S UBRZANOM DEGENERACIJOM STABILIZACIJSKIH STRUKTURA U DONJOJ SLABINSKOJ KRALJEŽNICI}

\section{Jeleč, R. Turner, M. Franic, A. Korušić i K. Rotim}

Utjecaj orijentacije i asimetrije fasetnih zglobova na progresiju degenerativnih promjena kralježnice bio je predmetom mnogih istraživanja provedenih u zadnjih nekoliko desetljeća, no rezultati studija su još uvijek proturječni. Biomehanički uzrok ubrzane degeneracije stabilizacijskih struktura donje slabinske kralježnice je složen, no najvažniji čimbenici su kompresivno opterećenje i više frontalna orijentacija fasetnih zglobova koja pruža manji otpor sili rotacije. Aksijalna rotacija donje slabinske kralježnice je nesumnjivo povezana sa znatnim opterećenjem prstena diska te se čini da bi povećani opseg sekundarnih rotacijskih pokreta mogao biti još značajniji za progresiju degenerativnih promjena fibroznog prstena. Sukladno tome, više izražena asimetrija fasetnih zglobova mogla bi imati određenu ulogu u bržoj progresiji degeneracije diska u donjoj slabinskoj kralježnici, na što ukazuju i mnoga novija istraživanja. Više sagitalna orijentacija fasetnih zglobova u bolesnika s jače izraženim osteoartritisom fasetnih zglobova je najvjerojatnije povezana s degenerativnim remodeliranjem koje se često može vidjeti i u drugim sinovijalnim zglobovima. Također postoji mogućnost da je povezana i s adaptacijom na djelomični gubitak fiziološke slabinske lordoze, jer obje pojave koincidiraju s poodmaklom životnom dobi.

Ključne riječi: Intervertebralni disk, degeneracija; lumbalna - patologija; Kralježnica, lumbalna radiografija; Magnetska rezonancija, snimanje; Osteoartritis; Biomehanički fenomeni; Tlak; Tropizam 